\title{
Desain Kemasan Buah Pasca Panen Dengan Fungsi Higroskopis Melalui Pemanfaatan Komposit Limbah Kayu
}

\author{
DUDY WIYANCOKO ${ }^{1}$, IMAM DAMAR DJATI ${ }^{2}$, SLAMET RIYADI ${ }^{3}$, BISMO JELANTIK ${ }^{4}$ \\ 1, 2,3,4 Desain Produk Industri, Fakultas Seni Rupa dan Desain, Institut Teknologi Bandung, Jl. Ganesa 10, \\ Bandung 40132, Indonesia
}

E-mail: 1dudywiyancoko@gmail.com, ${ }^{2}$ imamdj@yahoo.com, ${ }^{3}$ dhiesign@yahoo.com, ${ }^{4}$ bismojo@gmail.com

\begin{abstract}
Penelitian ini bertujuan untuk memaparkan hasil pemanfaatan material ramah lingkungan untuk pengembangan desain kemasan buah, khususnya kemasan dari tahap pasca-panen hingga pasar pengecer. Studi kasusnya adalah kemasan buah mangga gedong gincu di beberapa wilayah di Jawa Barat. Sedangkan material ramah lingkungan yang dimanfaatkan adalah tatal kayu yang mudah didapat sebagai limbah proses pengerjaan produk perkayuan. Hasil dari eksperimentasi penelitian ini adalah: (1) Tatal kayu memiliki fungsi higroskopis, yakni kemampuan untuk menyerap molekul air dan mampu menjadi material kemasan yang menahan buah agar tidak cepat busuk; (2) Desain kemasan buah yang dihasilkan dari bahan tatal kayu dapat dikembangkan sebagai wadah buah higroskopis dan kemasan buah secara moduler sehingga mudah untuk dibuat, dibawa, ditumpuk, dan digunakan oleh konsumen dengan tampilan yang dibuat menarik.
\end{abstract}

Kata kunci : kemasan, desain, komposit limbah kayu

\section{Post-harvest Fruit Packaging Design with Higroscopic Function through Utilization of Wood Waste Composite}

\begin{abstract}
This research aims to explain the potential and application of biodegradable material in fruit packaging design, specifically those prepared for post-harvest stage to the retail market. As a case study is packaging of mango 'gedong gincu' which is an excellent product of fruit farming in some regencies in West Java. Biodegradable material in this research is the use of wood shavings as a waste material obtained from woodworking process. The results of experimentation from this research are: (1) Wood shavings have hygroscopic function, that is having ability to absorb water molecules so the packaged fruit is not easy to rot; (2) The design of fruit packaging made from wood shavings can be developed as a hygroscopic fruit container and a modular packaging that is easy to make, deliver, stack, and used by the consumer with a good appearance.
\end{abstract}

Keywords : packaging, design, wood waste

Peer Review : 2 - 19 Januari 2018, Acepted to Publish 22 Januari 2018

\section{PENDAHULUAN}

Produk kemasan merupakan salah satu hasil olahan material untuk melindungi komoditi maupun pro-duk fungsional lainnya. Kegunaan kemasan tidak saja untuk melindungi dan membawa suatu komo-diti saja, melainkan memberikan informasi, kenyamanan, daya tarik bahkan mampu merepresentasikan identitas produk. Bahkan oleh Andrew Dent dan Leslie
Sherr (2015), kemasan menjadi bernilai tinggi apabila membuka kesadaran bagi para pelaku usaha tentang pelestarian lingkungan. Namun demikian, eksistensi kemasan dalam kegiatan komersial para pengusaha kecil selalu menjadi sesuatu yang dikesampingkan bahkan dilupakan. Tidak jarang petani bahkan pengusaha masih meremehkan arti kemasan, mereka menganggap kemasan hanya sebagai beban tambahan biaya produksi. Akibatnya mereka cenderung meng-gunakan kemasan yang seadanya, misalnya tas plastik hasil daur ulang bahan berbahaya, 
dan menganggap kemasan masih sebagai wadah atau pembungkus semata. Dalam kaitan inilah tim peneliti mengusulkan agar petani buah maupun pengusaha kecil-menengah meletakkan desain kemasan sebagai pertimbangan kualitas produk pasca panen, menimbang banyak sekali potensi buah lokal yang selama ini hanya dikemas seadanya.

Sejauh ini kemasan mulai diperhatikan oleh para pelaku usaha kecil menengah melalui himbauan, pelatihan, dan loka-karya, namun sayang perkembangannya masih sebatas modifikasi-modifikasi di tingkat tampilan, olahan bentuk dan varian grafisnya.

Inovasi desain kemasan seharusnya sampai pada pemanfaatan hibriditas material, baik material konvensional maupun non-konvensional, seperti material komposit, sehingga mampu menghasil-kan fungsi dan bentuk kemasan yang memiliki fungsi higroskopis dan terpakai secara luas. Sebab sebagaimana diingatkan oleh Klimchuk dan Krasovec (2006), tujuan esensial desain kemasan adalah bukan pada tampilannya yang menarik namun pada kemampuannya untuk memberi solusi atas permasalahan yang ada.

Pemerintah menegaskan harapannya agar sektor ekonomi kreatif berperan besar menjadi tulang punggung perekonomian nasional. Saat ini sumbangan sektor kreatif ini baru mencapai 6 - 7\%, padahal ekonomi kreatif yang berbasis kreativitas dan inovasi ini seharusnya bisa menjadi keunggulan baru di Indonesia dalam menjawab tantangan globalisasi dan pembangunan berkelanjutan. Ma-kin jelas bahwa daya saing suatu provinsi tidak lagi diukur dari biaya produksi, seperti upah tenaga kerja yang murah dan keberadaan bahan baku, tetapi juga sektor lain seperti inovasi material, desain produk dan logistik yang efisien. Dalam kaitan ini sektor ekonomi kreatif yang ditopang oleh bidang-bidang industri kreatif ini perlu mengembangkan potensi, salah satu yang utama adalah pengembangan di bidang desain kemasan. Sebagaimana industri di negara yang sadar akan manfaat desain kemasan seperti Jepang dan negara industri lain, desain kemasan bagi sektor pertanian di Indonesia harus menjadi prioritas pertimbangan yang utama.

Sebagai contoh pertanian buah di Jawa Barat, desain kemasan masih belum terlalu dipedulikan sebagai pertimbangan utama. Pelaku Usaha Kecil Menengah (UKM) di Jabar sekitar 7,4 unit (data 2008), dan hanya $10 \%$ yang peduli dan menerapkan peran kemasan sebagai nilai tambah produk. Padahal secara teori, kemasan dapat meningkatkan nilai jual produk $30 \%$. Kendalanya adalah produsen kemasan menetapkan minimal pesanan Rp. 25 juta untuk satu merk kemasan tertentu, sehingga pelaku UKM

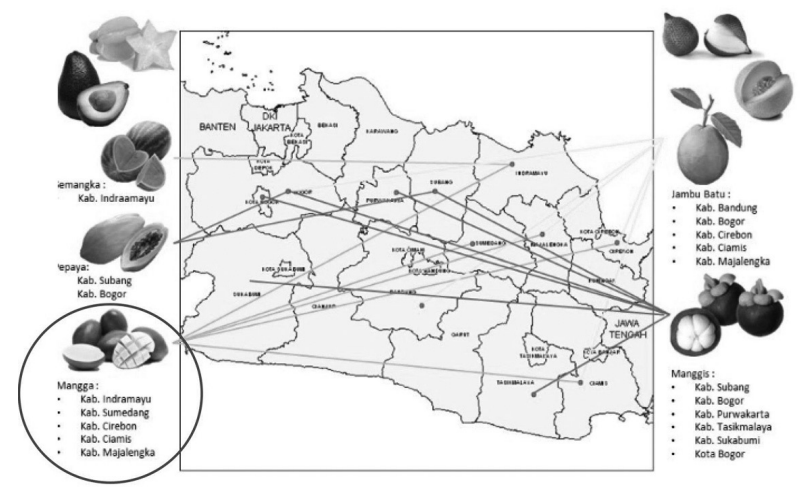

Gambar 1.

Mangga dan Pemetaan Lokasi Buah di iawa Barat (Sumber: Dinas Pertanian Tanaman Pangan Provinsi Jawa Barat).

sulit membelinya. Selain itu masih banyak faktor penentu lainnya, yakni: persyaratan higienitas dan label halal, selain edukasi akan pentingnya peran kemasan kepada pelaku UKM yang masih rendah. Dalam penelitian ini telah dilakukan studi terhadap 8 jenis buah yang menjadi produk unggulan Jawa Barat (Gambar 1). Dari sejumlah jenis buah tersebut dipilih mangga gedong gincu yang tingkat kebutuhan akan ke-masan higroskopisnya tinggi, khususnya di Kabupaten Majalengka, Indramayu, Ciamis, dan Cirebon di Jawa Barat. Di sejumlah kabupaten ini sangat diperlukan kualitas kemasan yang didesain dengan baik untuk pemenuhan kebutuhan pasar ekspor dan domestik.

\section{Mangga Gedong Gincu Sebagai Komoditi Unggulan}

Mangga gedong gincu adalah salah satu jenis varietas mangga (Mangifera Indica). Mangga jenis ini banyak dibudidayakan di Kabupaten Maja-lengka, Kabupaten Indramayu, Sumedang, Ciamis dan Cirebon. Di Kabupaten Majalengka, pembudidayaannya adalah di Desa Sidamukti, Desa Panyingkiran dan Kelurahan Munjul. Sedangkan di Kabupaten Indramayu hampir semua keca-matan merupakan penghasil mangga gedong gincu. Mangga gedong gincu merupakan komoditi pertanian andalan untuk pasar ekspor maupun domestik. Masa panen dari mulai tanam adalah selama tiga tahun. Panen raya dilakukan setiap bulan September-November setiap tahunnya. Hal ini menjadi permasalahan karena mangga gedong gincu sulit diperoleh di luar musim panennya, kecuali kelompok tani di wilayah tertentu mampu menerapkan teknologi pola tanam yang baik sehingga bisa melakukan panen di luar musim, yakni sejak di bulan Juni. Permasalahan lainnya pada buah mangga adalah lalat buah, yang menyebabkan kebusukan. Tanpa lalat buah, mangga gedong gincu dapat bertahan selama kurang lebih 15 hari. 


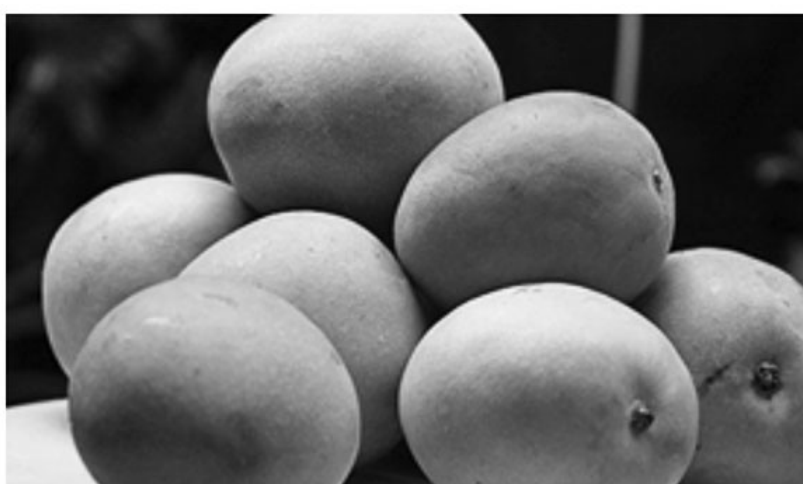

Gambar 2. Mangga Gedong Gincu

Perbedaan antara mangga gedong gincu produksi Majalengka dengan indramayu adalah dari ukuran dan warnanya. Mangga gedong gincu Majalengka ukurannya lebih besar dengan warna kuning di ujungnya. Sedangkan mangga Indramayu ukur-annya lebih kecil, bentuknya yang bulat, dengan warna merah yang dominan. Kabupaten Indramayu merupakan satu-satunya penghasil mangga gedong gincu dan hingga saat ini tidak melakukan ekspor mangga jenis apapun karena kendala pada aspek pemodalan, pemasaran, dan distribusi, termasuk persoalan kemasannya. Dinas pertanian hanya melakukan pembinaan teknis pembudidayaan sampai dengan panen. Sedangkan mangga gedong gincu Majalengka cukup diminati pasar ekspor dan domestik karena ukuran buahnya lebih besar. Namun demikian kadar airnya lebih banyak sehingga cepat membusuk bila tidak terkemas secara baik. Pengangkutan dan pendistribusian mangga gedong gincu biasanya cukup dengan menggunakan peti kayu. Pensortiran buah mangga dilakukan berdasarkan berat dan ukuran. Misalnya untuk supermarket atau ekspor, berat perbuahnya adalah 20 ons ke atas. Secara teknis pengangkutan mangga gedong gincu di daerah yaitu dengan menggunakan boks (box) yang terbuat dari plastik dan berkapasitas kurang lebih 20 kilogram. Pengiriman dengan menggunakan boks plastik adalah untuk mengangkut buah mangga dalam jumlah besar, karena ketika sampai di tempat tujuan buah akan segera dipindahkan dan dipajang oleh pedagang. Boks merupakan milik pengepul yang harus dikembalikan oleh pedagang.

\section{Kemasan Buah Pasca Panen}

Kemasan buah yang diperlukan dari tahap panen hingga tahap pasar retail terdiri dari berbagai macam, yakni: kemasan panen, kemasan pasca-sortir dari kelompok petani, kemasan khusus untuk ekspor dan untuk domestik, serta kemasan di pasar retail. Dalam penelitian ini difokuskan pada kemasan untuk pasca sortir, pasar retail dan desain kemasan untuk konsumen (tanda lingkaran berlatar gelap di Gambar 3), karena ketiganya memerlukan perencanaan dan desain kemasan higroskopis yang baik.

\section{Jenis Kebutuhan Kemasan Hasil Pertanian Buah}

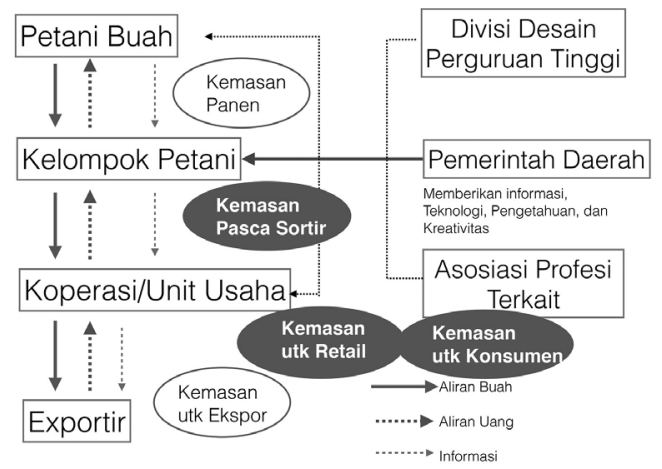

Gambar 3. Alur Kebutuhan Pengemasan dari Tahap Panen hingga Pasar Retail.

Alur pengemasan buah mencakup beberapa tahap yakni:

(a) Persiapan: trimming (membuang bagian yang tidak diinginkan seperti batang, lebihan akar, kulit, dan sebagainya), delatexing (membuang getah yang masih keluar agar tidak mengotori produk), cleaning (membersihkan produk dan membuang kontaminan yang masih menempel dengan pencucian, penyemprotan, pengelapan), sorting dan garding (menyisihkan produk yang tidak memenuhi syarat mutu, menggolongkan mutu sesuai dengan permintaan pasar);

(b) Perlakuan pada produk: pematangan, curing, pelapisan, pemeriksaan hama dan penyakit;

(c) Pengemasan untuk distribusi baik melalui kemasan primer maupun sekunder;

(d) Distribusi dan penyimpanan atau, bila diperlukan adalah pra-pendinginan dan penyimpanan dingin.

Dalam penelitian ini, desain kemasan buah ditargetkan menjadi kemasan yang mampu meningkatkan kualitas komoditi produk secara keseluruhan. Pertimbangan ini, sebagaimana disyaratkan konsep green packaging, mengondisikan kemasan buah untuk menggunakan material yang bersahabat pada alam, yakni komposit dengan limbah tatal kayu yang memiliki fungsi penetralisir kelembaban suhu dan penahan benturan fisik. Tatal kayu merupakan limbah dari proses penyerutan kayu solid. Tatal kayu dapat diperoleh dengan mudah di pasaran, baik dari lokasi-lokasi pengolahan kayu solid, ataupun membelinya dalam bentuk tatal dengan berbagai ukuran. Material ini memiliki karakteristik bentuk yang tidak beraturan karena merupakan limbah dari pengolahan industri kayu. Jumlah hasilan tatal kayu relatif mudah untuk diperoleh dan memiliki nilai ekonomi 
yang relatif murah.

\section{METODE PENELITIAN DESAIN}

Pendekatan yang dilakukan adalah pendekatan eksplorasi material (material exploration approach). Bahan tatal kayu diolah kemanfaatannya untuk mampu mencapai fungsi tertentu, yakni sebagai material dasar kemasan dan sebagai pelindung buah dari proses percepatan pembusukan. Untuk menjadikannya sebagai kemasan, metode yang digunakan adalah perancangan produk dengan penekanan pemecahan masalah. Metode ini mengandalkan proses kreatif dan eksperimentasi material dengan beberapa studi sebagai berikut:

Studi aspek teknis dan faktor keberlanjutan material komposit biodegradable dari bahan tatal kayu limbah produksi sebagai material inti dalam lini produksi kemasan. Studi ini dimulai dengan kajian keunggulan sifat material komposit untuk dipertemukan dengan tingginya tingkat kebutuhan akan kemasan dengan fungsi higroskopis, mengurangi resiko pembusukan, penetral suhu, elastisitas, tahan benturan, kemudahan untuk didaur ulang, tahan perubahan cuaca, lentur dibentuk, dan nyaman digunakan.

Studi pengembangan desain dan usabilitas produk berbahan material komposit limbah tatal kayu. Caranya adalah dengan melakukan pengeraman buah di dalam tatal kayu beserta hasil perbandingan tingkat kematangan buahnya, baik dalam kondisi terkemas di material tatal kayu maupun tidak terkemas dalam kondisi udara normal. Setelah eksperimen fungsi higroskopis, maka dilaksanakan proses desain, mulai dari tahap perumusan konsep desain awal, sketsa desain, 3-D prototyping dan desain final.

Studi sistem produksi produk berbahan material komposit biodegradable dari aspek produksi. Dalam tahap ini dievaluasi permasalahan-permasalahan yang terkait dengan persyaratan keamanan, keselamatan, kenyamanan dan kesehatan kerja.

\section{ANALISIS DAN EKSPERIMENTASI HIGROSKOPIS}

Pada eksperimen yang dilakukan di tahap ini, tatal kayu dikondisikan pada lingkungan yang melingkupi buah. Eksperimen ini bertujuan untuk mengetahui perubahan yang terjadi pada kondisi buah yang dikemas dengan menggunakan tatal kayu dengan cara membandingkannya dengan buah yang dikondisikan pada suhu ruangan normal.
Tabel 1: Daftar buah dan sayuran yang digunakan dalam eksperimen

\begin{tabular}{|c|l|c|c|c|c|l|}
\hline No & Buah/Sayuran & Eksp. & Tanggal & $\begin{array}{c}\text { Berat } \\
\text { (gr.) }\end{array}$ & $\begin{array}{c}\text { Tatal } \\
\text { (gr.) }\end{array}$ & Ket. \\
\hline 1 & Mangga Gedong & 1 & 3 Okt 2016 & 1294 & 200 & Exp.1 \\
\hline 2 & Pisang Cavendish & 1 & & 1700 & 200 & \\
\hline 3 & Jeruk Medan & 1 & & 792 & 200 & \\
\hline 4 & $\begin{array}{l}\text { Apel Malang } \\
\text { (manalagi) }\end{array}$ & 1 & & 778 & 200 & \\
\hline 5 & Mangga Gedong & 2 & 19 Okt 2016 & 1636 & 200 & Exp.2 \\
\hline 6 & Pisang Cavendish & 2 & & 1076 & 200 & \\
\hline 7 & Tomat & 2 & & 592 & 200 & \\
\hline 8 & Sawi Putih & 2 & & $468 ; 562$ & 200 & \\
\hline 9 & Pisang Cavendish & 3 & 28 Okt 2016 & 1068 & 200 & Exp.3 \\
\hline 10 & Pisang Mas & 3 & & 942 & 200 & \\
\hline 11 & Alpukat & 3 & & 2038 & 200 & \\
\hline
\end{tabular}

Tabel di atas merupakan tabel jenis dan berat buah dan sayur yang dijadikan objek dalam eksperimen, serta berat tatal yang digunakan sebagai perbandingan dengan berat dari buah dan sayur yang diujikan.

Pada eksperimen awal, empat jenis buah, yaitu mangga, pisang, jeruk, dan apel diuji secara bersamaan. Keempat buah tersebut masing-masing dibagi menjadi dua kelompok. Kelompok pertama dikondisikan kedap udara dengan menggunakan tatal, dan kondisi kedua dikondisikan pada suhu ruangan dalam kondisi terbuka (Gambar 4).

Kedua kelompok buah ini dibiarkan dalam kondisi tersebut selama 10 (sepuluh) hari.

Parameter yang diamati dalam eksperimen ini di antaranya adalah suhu, kelembaban, warna buah dan kondisi fisik buah lainnya. Dari ekseperimen ini didapatkan hasil sebagai berikut (Gambar 5):

Pada apel, terlihat perbedaan tekstur kulit. Apel yang diletakkan di ruang terbuka memiliki tekstur kulit keriput dan lebih lunak serta muncul noda-noda kehitaman pada bagian-bagian tertentu. Berbeda dengan apel yang terbungkus dalam serbuk tatal kayu yang masih awet

Demikian pula dengan buah jeruk. Tekstur kulit jeruk yang diletakkan di ruang terbuka menjadi lebih keriput, lebih lunak dan lebih berubah warnanya dibanding dengan jeruk yang disimpan bersama tatal kayu yang hanya sedikit mengalami perubahan warna dan cenderung tetap yaitu kehijauan.

a). Pisang yang diletakkan di ruang terbuka memi-liki tekstur kulit yang semakin lunak serta muncul noda-noda hitam pada hampir seluruh bagiannya. Pada 


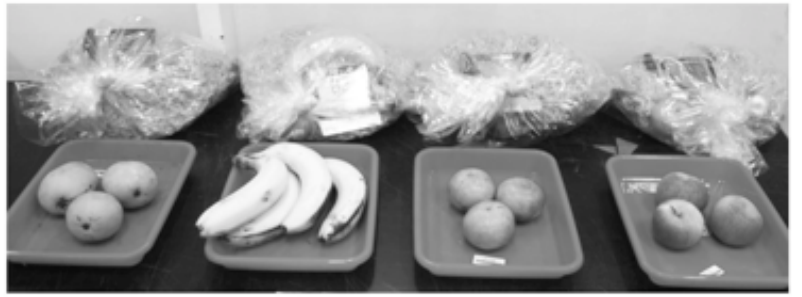

Gambar 4. Proses eksperimen penyimpanan buah dengan dua kondisi: disimpan di bungkusan tatal kayu (atas) dan dibiarkan di suhu ruang terbuka (nampan bawah).

pisang yang disimpan dengan tatal kayu, perubahan warna yang terjadi sejak hari pertama tidak signifikan dan cenderung tetap kuning dengan sedikit garisgaris menghitam pada beberapa bagian kulitnya.

b). Pada mangga gedong gincu, terlihat perbedaan tekstur kulit. Mangga yang diletakkan di ruang terbuka memiliki tekstur kulit yang semakin lunak serta muncul noda-noda hitam pada hampir seluruh bagiannya. Berbeda dengan mangga yang disimpan bersama tatal kayu, perubahan warna yang terjadi sejak hari pertama tidak signifikan dan cenderung tetap oranye.

Perbedaan rasa juga terjadi pada buah-buahan tersebut. Pisang yang disimpan dalam tatal, rasa yang dihasilkan menjadi seperti terfermentasi, sedangkan pada mangga yang disimpan di kondisi ruangan rasa menjadi matang dan keasamannya meningkat (membusuk). Tekstur daging pada mangga yang disimpan di tatal cenderung tetap baik sejak hari pertama dan hanya sedikit sekali mengalami pelunakan. Berbeda dengan mangga yang diletakkan di ruang terbuka, tekstur daging buahnya menjadi sangat lunak dan berair.

Dengan demikian, sebagaimana kayu solid, tatal kayu pun memiliki sifat higroskopis. Higroskopis adalah kemampuan suatu zat untuk menyerap molekul air dari lingkungannya baik melalui absorbsi atau adsorpsi. Suatu zat disebut higroskopis jika zat itu mempunyai kemampuan menyerap molekul air yang baik.

\section{Pengembangan Desain Kemasan}

Pengembangan desain kemasan dilakukan secara terintegrasi dalam dua tahapan utama, yakni: pengembangan material tatal kayu sebagai material inti untuk desain produk kemasan. Disusul dengan tahap pengembangan desain untuk menghasilkan beberapa usulan desain kemasan di alur distribusi pasca-panen Dalam pengertian ini, sebagaimana diulas oleh Patino (2012) tentang proses mendesain, tahap eksplorasi material me-rupakan tahap yang mutlak

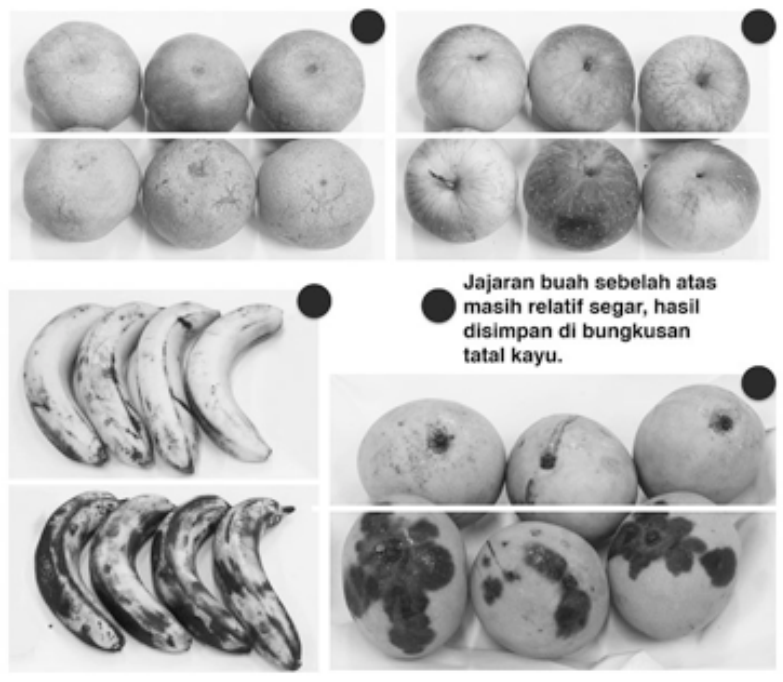

Gambar 5. Hasil eksperimentasi penyimpanan buah dengan tatal kayu (jajaran dengan tanda bulat) dan penyimpanan di suhu ruang.

dilakukan sebelum masuk dalam tahap perumusan konsep desain. Oleh Alesina dan Lupton (2010) ditegaskan bahwa dengan melakukan tahap eksplorasi material secara langsung (learning by doing) di awal proses mendesain, maka kemungkinan untuk lebih mendapatkan inspirasi dan ide desain akan menjadi lebih tinggi, dibandingkan hanya mengandalkan sketsa-sketsa ide.

Tahap pertama adalah studi aspek teknis dan fak-tor keberlanjutan material komposit biodegradable dari bahan tatal kayu limbah produksi sebagai material inti dalam lini produksi kemasan. Tahapan ini dimulai dengan kajian keunggulan sifat material komposit yang sudah dilakukan di Laboratorium Desain Produk Industri FSRD ITB, misalnya: lembar papan dan lembar kertas dari tatal kayu (Gambar 6). Karakter material diolah melalui 3 pendekatan: (a) material sebagai struktur kemasan: pembuatan elemen-elemen struktur maupun modular; (b) material sebagai bidang kemasan, dibentuk berupa bidang dengan ketahanan menyangga beban tertentu; (c) material sebagai permukaan kemasan, penggabungan antara permukaan satu material dengan material lainnya dengan memperhitungkan sisi kenyamanan penggunaan. Seluruh pendekatan ini diarahkan untuk target pemecahan masalah higroskopis dalam desain kemasan (bentuk, fungsi dan makna representasinya). Kajian sifat material ini selanjutnya dipertemukan dengan tingginya tingkat kebutuhan akan kemasan dengan fungsi higroskopis, mengurangi resiko pembusukan, penetral suhu, elastisitas, tahan benturan, kemudahan untuk didaur ulang, tahan perubahan cuaca, lentur dibentuk, dan nyaman digunakan.

Berdasarkan hasil eksperimen dapat disimpulkan adanya potensi pemanfaatan tatal kayu untuk desain kemasan buah. Di antaranya sebagai berikut: 

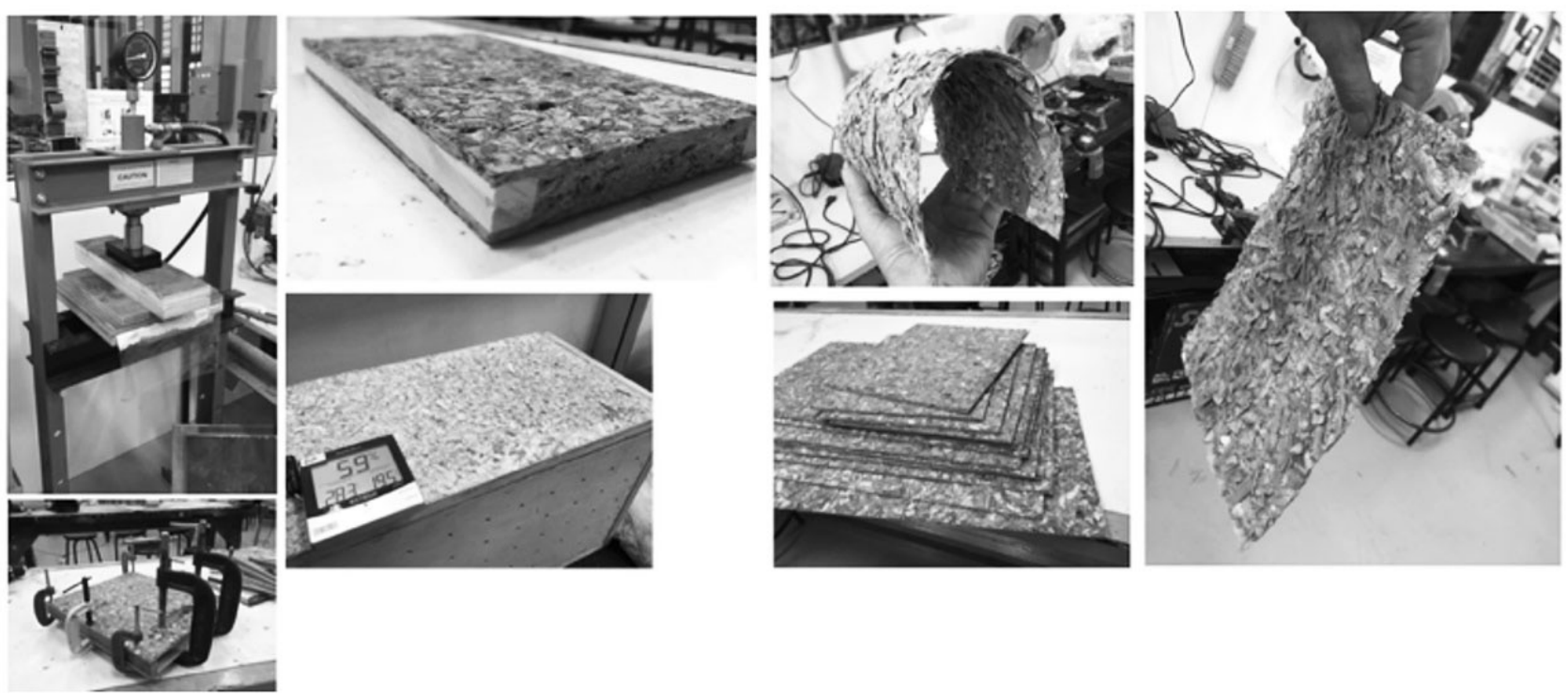

Gambar 6. Eksperimen lembar papan dan lembar kertas dari limbah tatal kayu.

1). Sebagai wadah penyimpanan sementara atau wadah penyimpanan saat pengangkutan, baik dalam bentuk bidang papan dan lembar kertas tebal $(>0,3$ $\mathrm{cm})$. Karena bentuk dan ukurannya yang kecil dan tidak berstruktur, material tatal kayu memiliki kemungkinan pengembangan bentuk yang sangat luas.

2). Material tatal kayu menyerap uap air yang mempengaruhi kelembaban dalam wadah penyimpanan selama masa pengangkutan menggunakan bak semi terbuka (ditutup terpal, tanpa pendingin udara). Sifat higroskopis material ini adalah serapan kandungan air mulai dari 5\%-90\% yang semakin kecil densitas kayunya, semakin higroskopis sifat yang dimilikinya.

Menurunkan resiko kenaikan suhu yang berlebihan dan menetralisir kenaikan suhu selama masa penyimpanan. Dari hasil uji organoleptik yang dilakukan diketahui bahwa tatal kayu memiliki kemampuan untuk menetralkan suhu tinggi;

1). Meredam getaran dan menurunkan resiko cacat fisik pada buah dan atau sayuran dalam penyimpanan, terutama selama masa pe-ngangkutan;

2). Menjamin tetap terjaganya sirkulasi oksigen dalam wadah penyimpanan. Ketika tatal kayu yang lembab dikeringkan, material ini dapat kembali ke bentuk dan kelembaban semula mendekati 100\% (resilient), sehingga berpotensi untuk dapat digunakan berulang kali.

Tahap kedua adalah studi pengembangan desain dan usabilitas produk berbahan material komposit limbah tatal kayu. Setelah eksperimen fungsi higroskopis, maka dilaksanakan proses desain, mulai dari tahap perumusan konsep desain awal, sketsa desain,
3-D prototyping dan desain final. Dalam tahap ini, mendesain kemasan memang berurusan dengan bentuk dan materialnya, agar memenuhi persyaratan lini produksi, distribusi, promosi, konsumsi, hingga proses daur ulangnya.

Berdasarkan hasil observasi yang telah dilakukan pada tahap studi lapangan maka dirumuskan pengklasifikasian jenis kemasan yang dibutuhkan dalam pendistribusian buah sejak dari tahap pemanenan hingga sampainya produk ke tangan konsumen (retailer), yakni desain kemasan buah untuk 3 (tiga) alur distribusi:

1). Desain 1: Wadah kemasan dari Petani ke Gudang/ Pengepul.

\section{2). Desain 2: Kemasan dari Gudang/Penge-pul ke Pengecer.}

3). Desain 3: Kemasan dari Pengecer ke Konsumen.

Material yang digunakan pada ketiga kemasan tersebut adalah kombinasi tatal kayu dan polyvinyl acetate (PVAc). Tatal kayu diolah menjadi material maju dengan menggunakan kombinasi material lain, seperti PVAc dan pulp. Sebelum material ini diolah menjadi produk akhir, material ini diolah terlebih dahulu menjadi bentuk lembaran komposit keras, lembaran kertas pulp tatal kayu, dan bubur pulp tatal kayu yang dicetak langsung menjadi bentuk akhir. Menentukan jenis produk kemasan yang akan dikembangkan perlu me-lakukan analisis

terhadap alur distribusi buah pasca panen. Analisis dilakukan berdasarkan hasil survei lapangan dan observasi penggunaan kemasan yang disarikan dalam 


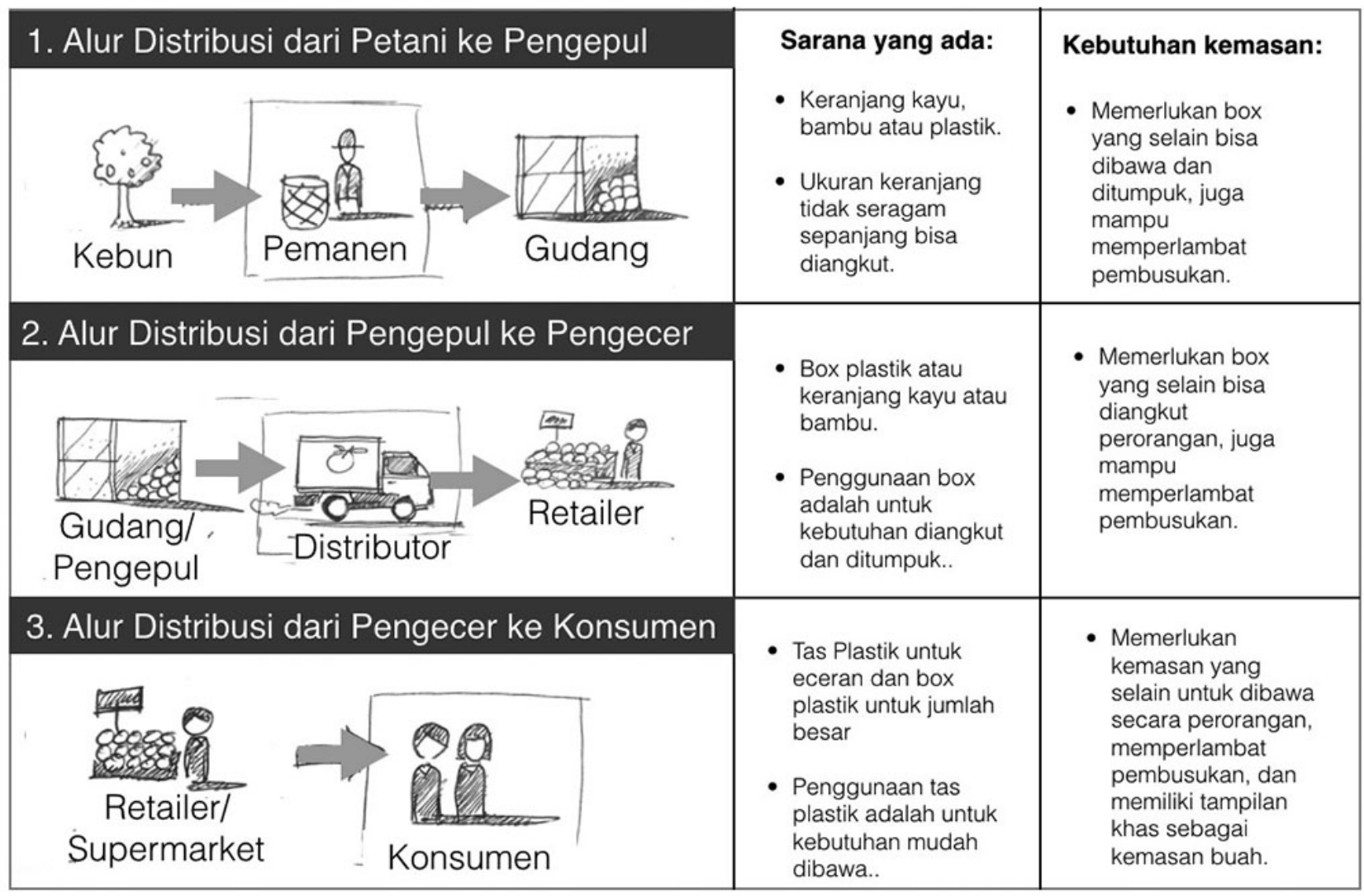

Tabel 2. Klasifikasi alur distribusi dan jenis kemasan yang dikembangkan desainnya.

Tabel 2.

\section{Desain Kemasan Untuk Alur Distribusi 1, Dari Pemanen Ke Pengepul}

Berdasarkan analisis survei dan proses pengembangan desain, dibuat kemasan yang berfungsi sebagai wadah (container) dan memiliki fungsi higroskopis (mampu menyerap molekul air untuk memperlambat pembusukan).

Wadah kemasan secara prinsip merupakan bentuk dasar kotak (box) berukuran panjang $60 \mathrm{~cm}$, lebar $30 \mathrm{~cm}$, dan tinggi $40 \mathrm{~cm}$ yang memuat sejumlah buah mangga gedong gincu. Dua sisi kotak di-berikan sarana pegangan untuk memudahkan kemasan ini diangkat maupun ditumpuk. Material yang digunakan adalah lembar tatal kayu dan perekat polyvinyl acetate (PVAc) yang melapisi multipleks, sehingga dinding kemasan tetap keras namun memiliki fungsi higroskopis dan penahan benturan fisik. Kotak ini digunakan oleh petani pemanen, terutama untuk penyimpanan buah dengan cara ditumpuk berjajar, selama menuju gudang atau pengepul. (Gambar 7). Kotak ini merupakan hasil pengembangan bentuk kemasan yang paling dasar, yang nantinya memerlukan desain lebih lanjut terhadap bagian-bagian detail dari sistem penutup, pegangan, bidang alas untuk penumpukan, dan sebagainya.

\section{Desain Kemasan Untuk Alur Distribusi 2, Dari Pengepul Ke Pengecer}

Desain kemasan ini menawarkan bentuk kemasan buah dalam jumlah tertentu, bergantung pada besar-kecilnya mangga yang disimpan. Teknik yang digunakan dalam pemanfaatan tatal kayu adalah tidak berupa papan yang melapisi keseluruhan kemasan, melainkan dikemas dalam bentuk cartridge atau bantalan-bantalan yang dapat dilepas dan dipasang sesuai dengan kebutuhan pengondisian udara. Bantalan humektan (pengondisi udara dan kelembaban di dalam kemasan) ini dapat digunakan berulang-ulang. Apabila sudah terlalu lembab, bantalan-bantalan ini dapat di-keringkan di udara terbuka ataupun dijemur (Gambar 8).

Desain kemasan untuk alur distribusi ke-2 (dari pengepul ke pengecer) ini tetap merupakan kemasan yang terbuat dari kotak tatal kayu berukuran panjang $60 \mathrm{~cm}$, lebar $30 \mathrm{~cm}$ dan tinggi $40 \mathrm{~cm}$, yang sebelumnya sudah dibentuk menjadi lembaran kertas dengan berbagai ketebalan. Lembaran kertas setebal minimal $3 \mathrm{~mm}$ ini dihasilkan dengan pengepresan sehingga kadar air dalam lembar tersebut dapat terkurangi. Jenis tatal kayu yang digunakan dalam 

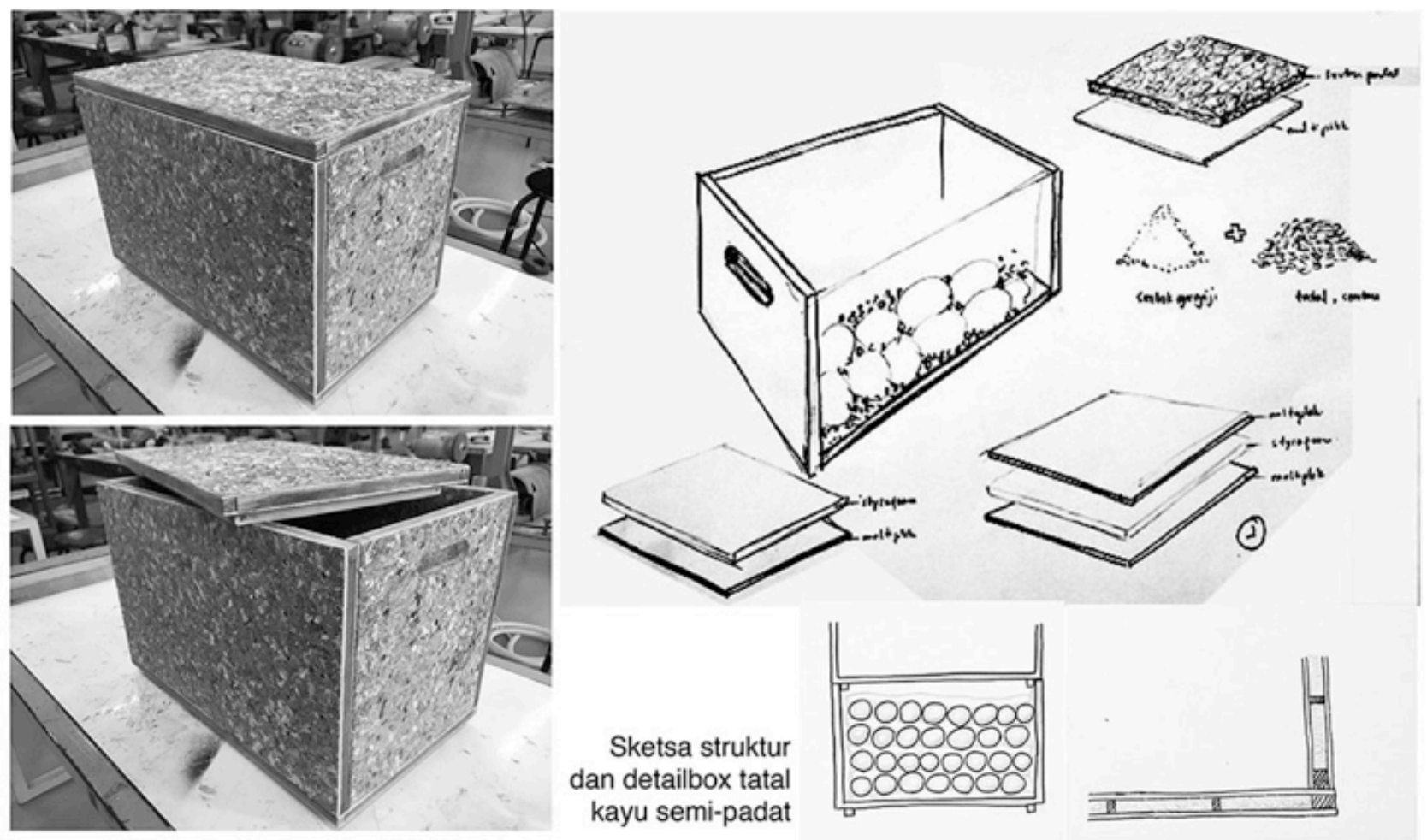

kayu semi-padat

Gambar 7. Desain wadah buah dari tatal kayu untuk penyimpanan buah di tahap pengepul dan gudang.

bantalan merupakan komposit campuran dari pulp dengan tatal kayu.

Desain kemasan lembar tatal kayu yang dilengkapi dengan humektan ini digunakan pada saat distribusi dari gudang pengepul menuju ke pengecer (retailer). Dalam tahap ini kemasan yang menyerupai kotak kardus ini perlu diberi berbagai tanda grafis yang memuat segala informasi tentang hasil sortir, kode buah, dan informasi lainnya. Perlakuan terhadap kemasan ini adalah sama halnya dengan kemasan kotak untuk distribusi lainnya, yakni diberi tanda, ditimbang, disegel, diangkat secara peorangan, ditumpuk dan diangkut dengan mobil. Jenis komposisi komposit tatal kayu yang digunakan dalam bantalan humek-tan terbangun dari rasio antara $80 \%$ tatal kayu dan $20 \%$ pulp kertas.

\section{Desain Kemasan Untuk Alur Distribusi 3, Dari Pengecer Ke Konsumen}

Desain kemasan untuk alur distribusi ke-3 (dari pengecer ke konsumen) pada prinsipnya merupakan desain kemasan buah yang ditargetkan memiliki tampilan yang baik namun masih tetap berfungsi higroskopis. Tujuan tampilan visual yang baik ini diwujudkan dalam bentuk yang khas, dengan tipe modular yang terbuat dari hasil cetakan bubur tatal kayu dan pulp (Gambar 9).
Setiap modul memiliki bentuk yang sama sehingga dalam penggunaannya tinggal disatukan. Untuk satu buah dibutuhkan satu pasang modul (2 modul), dan seterusnya. Ketika ditutup beberapa modul tersebut saling mengunci satu sama lain. Setelah tertutup kemasan dalam satuan per enam buah yang saling mengunci ini bisa dibawa dengan menggunakan tali atau bila dalam jumlah besar adalah dengan memasukkannya pada boks kardus.

Proses pembuatan model akhir untuk desain kemasan ini masih dilaksanakan dalam skala laboratorium, belum produksi masal, yakni dengan membuat model dalam bentuk sebenarnya dengan bahan polylactic acid (PLA) sebagai media cetakan untuk bubur tatal kayu-PVAc dan pulp kertas. Setelah cetakan selesai dibuat, selanjutnya adalah dengan mencetak bubur kertas tatal kayu tersebut hingga bentuknya sesuai dengan yang diinginkan dan akhirnya dikeringkan. Kemasan ini bisa mewadahi buah persatuan, atau per empat buah, atau per enam buah, dengan membawa konsekuensi besaran fisik dari kemasan tersebut. Semakin banyak buah yang dikemas, semakin besar rangkaian kemasan moduler ini. 


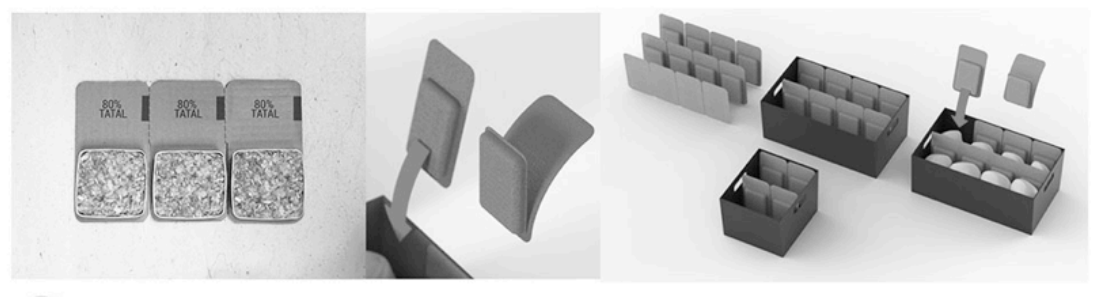

KEMASAN DISTRIBUSI
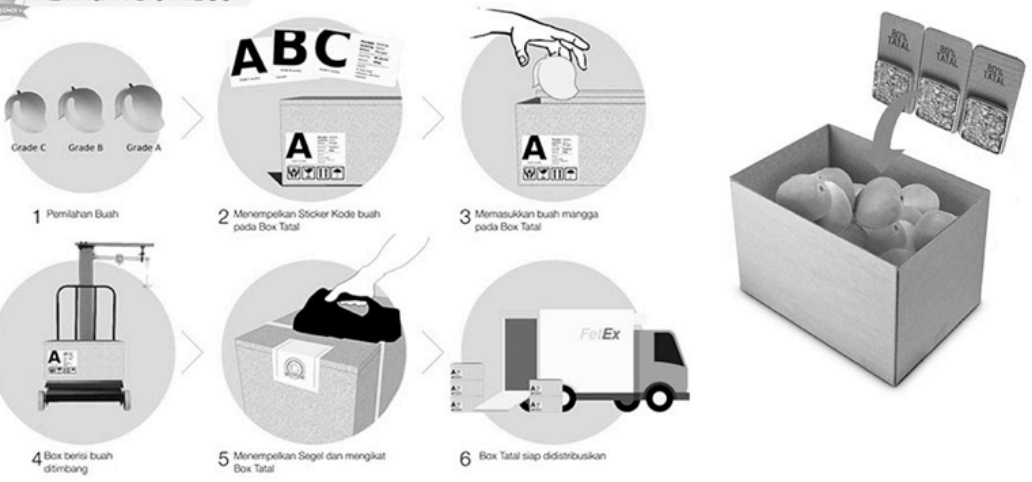

Gambar 8. Desain kemasan buah dari lembar kertas tatal kayu yang diselipkan bantalan-bantalan tatal kayu dan pulp untuk penyimpanan buah di tahap distribusi ke pengecer (retailer).

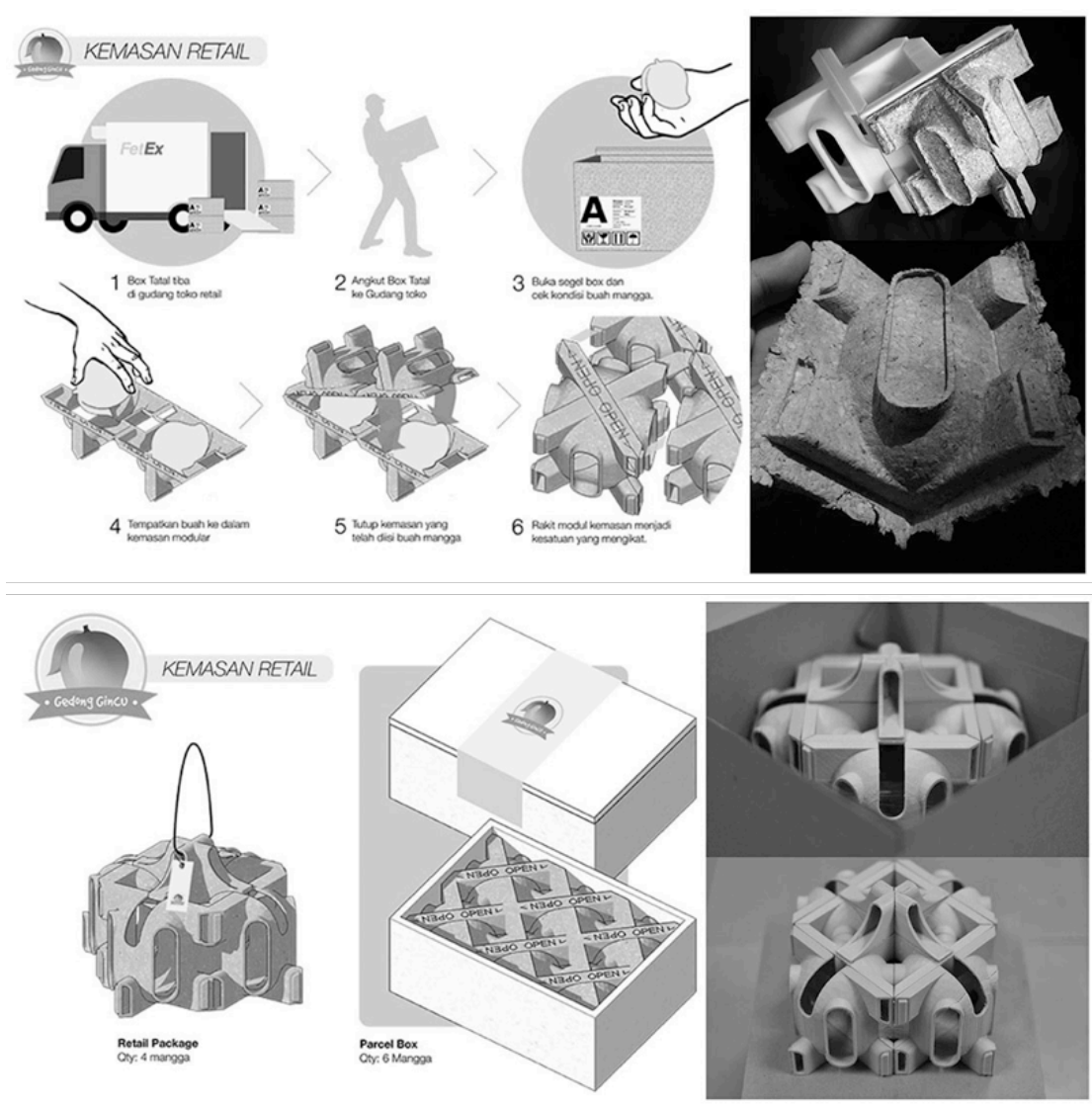

Gambar 9. Desain kemasan buah dari bubur kertas tatal kayu yang dibuat dengan pola moduler, yang ketika dirangkai bisa saling menutup untuk per emoat dan per enam buah mangga. Desain kemasan ini adalah untuk kemasan dari pengecer (toko buah) ke konsumen. 


\section{SIMPULAN}

Berdasarkan penelitian ini dihasilkan desain kemasan buah untuk komoditi pertanian unggulan dapat menggunakan material limbah tatal kayu. Studi kasus yang sudah dilakukan adalah dengan mengembangkan desain kemasan buah mangga gedong gincu, yang menjadi komoditi pertanian buah unggulan, khususnya di beberapa kabupaten di Jawa Barat. Hasil pertanian buah ini merupakan andalan hasil pertanian nasional, baik untuk pasar domestik maupun pasar ekspor yang membutuhkan kemasan yang baik dengan fungsi higroskopis (mampu menahan laju pembusukan).

Melalui eksperimentasi material, telah dibuktikan bahwa tatal kayu mampu memperlambat proses pematangan dan pembusukan. Selain itu, material ini juga dapat menetralisir suhu, sebab suhu cukup berpengaruh terhadap peningkatan produksi etilen, penurunan $\mathrm{O}_{2}$ dan peningkatan $\mathrm{CO}_{2}$, yang dapat diserap oleh tatal kayu. Dengan demikian tatal kayu merupakan material potensial untuk bisa dikembangkan lebih lanjut menjadi berbagai usulan desain produk kemasan. Bentuknya yang berupa hasil serutan bisa diolah menjadi serbuk dan bubur bilamana dibantu dengan menggunakan pulp maupun PVAc sebagai perekatnya. Sehingga material ini bisa dipres dan dikeringkan menjadi papan, kertas, maupun bubur tatal kayu untuk dicetak.

Pada tahap pengembangan desain, telah diperoleh tiga desain kemasan tatal kayu untuk mengantisipasi tiga alur distribusi kemasan buah mangga pasca-panen, yakni: (1) Wadah penyimpanan higroskopis di tahap penyimpanan oleh pengepul; (2) Kemasan distribusi dari pengepul ke pengecer atau atau tokotoko buah, dan; (3) Kemasan untuk pembelian oleh konsumen. Ketiga desain ini diakui oleh tim peneliti masih memiliki beberapa kelemahan dan perlu dianalisis lebih lanjut di penelitian berikutnya dengan melakukan uji-coba langsung kepada pengguna.

Uji-coba kemasan perlu dilaksanakan secara langsung kepada kelompok-kelompok tani pada tahap pasca-panen menuju pasar retail, yang mencakup:

(a) Evaluasi bentuk dan cara penggunaan kemasan;

(b) Uji kemampuan higroskopis dengan melakuk an uji nyata pada proses penyimpanan pasca-panen, sortir, pengemasan dan distribusinya ke pengecer (retailer). Bentuk kemasan perlu dievaluasi dalam kenyataan penggunaan sesungguhnya, agar mampu menjadi kemasan moduler yang mudah diangkut, ditumpuk, dibawa dengan tampilan yang baik, dan digunakan berulang, hingga diurai kembali ke tanah dengan cepat. Dalam skala laboratorium, kemasan dari material tatal kayu bisa memenuhi persyaratan tersebut, namun dalam skala produksi secara masal, kemasan ini perlu dikaji oleh industri material kemasan.

Melalui penelitian ini ditunjukkan pengembangan desain kemasan seharusnya tidak sebatas modifikasi di tingkat tampilan, namun sampai pada pemanfaatan hibriditas material sehingga mampu menghasilkan fungsi dan bentuk kemasan yang terpakai secara luas.

\section{DAFTAR RUJUKAN}

Alesina, Inna \& Lupton, Ellen. (2010), Exploring Material: Creative Design for Everyday Objects, Princetown Architectural Press.

Dent, Andrew H. \& Sherr, Leslie. (2015), Material Innovation: Packaging Design, Thames \& Hudson.

Klimchuk, Marianne Rosner \& Krasovec, Sandra A. (2006), Desain Kemasan, Penerbit Erlangga.

Santa, Patino LF. (2012), Using Material Exploration and Model-making as an Approach for the Development of Concepts in Design Project Courses dalam International Conference on Engineering and Product Design Education, Antwerp, Belgium. 